\title{
SOIL CONTAMINATION IN PUBLIC SQUARES IN BELO HORIZONTE, MINAS GERAIS, BY CANINE PARASITES IN DIFFERENT DEVELOPMENTAL STAGES
}

Luciane Madureira RIBEIRO(1), Ruth Massote DRACZ(1), Lanuze Rose MOZZER(1) \& Walter dos Santos LIMA(1,2)

\begin{abstract}
SUMMARY
To evaluate soil contamination by parasites in different developmental stages in public squares used as recreation and leisure areas for children in Belo Horizonte (MG, Brazil), 210 soil samples and 141 canine fecal samples were collected from 42 squares in the city. These samples were analyzed by the Caldwell and Caldwell technique and the Hoffman, Pons, and Janer technique. Of the samples analyzed, 89 (42.4\%) soil samples and 104 (73.5\%) fecal samples were contaminated with Ancylostoma sp., Toxocara sp., Trichuris sp., or Dipylidium sp. eggs; Giardia sp. cysts; or Isospora sp. oocysts. The commonest parasite was Ancylostoma sp., found in $85 \%$ soil and $99 \%$ fecal samples, followed by Toxocara sp., found in $43.7 \%$ soil and $30.7 \%$ fecal samples.
\end{abstract}

KEYWORDS: Soil contamination; Zoonoses; Public health; Dogs parasites.

\section{INTRODUCTION}

Pets play an important role in society because they promote the healthy development of children by augmenting accountability, sociability, and positive character traits ${ }^{6}$. In addition, the psychosocial effects of the relationship between man and dog are very beneficial, especially for people with special needs, such as the elderly and the disabled $^{9,19}$. These factors justify the considerable increase in the number of dogs in society today. However, this close physical contact with humans may be an important factor in the spread of diseases and parasites harbored by these animals. A significant zoonosis is visceral larva migrans (VLM), which is a syndrome in humans caused by the aberrant migration of Toxocara larvae, an ascarid with cosmopolitan distribution. Another parasitic zoonosis prevalent in tropical and subtropical regions is cutaneous larva migrans (CLM), mainly caused by Ancylostoma spp. The larva migrans syndrome generally is related to the presence of animals, mainly dogs and cats, in places where the man can become infected, such as beaches, parks, and public squares. Sandboxes at playgrounds and kindergartens, can sometimes serve as sources of infection. Children are the most frequently involved group, playing with soil and sand, coming in direct contact with infective larvae of nematodes that cause CLM, or in the case of LMV, to ingest soil or to take lead to the mouth objects contaminated with eggs of Toxocara ${ }^{12,13}$.

Despite the high proportion ${ }^{17,18}$ of canine endoparasites that are potentially zoonotic, and therefore represent a significant risk to public health, there are failures ${ }^{7,8,24}$ in the control of these parasites, which leads to persistent environmental contamination, and consequential risk of infection to both animals and humans. The clinical manifestations in humans vary with the species of parasite, but include visual ${ }^{21}$, neurological ${ }^{15}$, dermatological ${ }^{14}$, respiratory ${ }^{3}$, and enteric ${ }^{11}$ involvement, and there is a further impact on public health and economy ${ }^{23}$. A study to determine the prevalence of each parasite is necessary for the development of appropriate preventive and control measures. The city of Belo Horizonte has a population of 2,420,000 inhabitants and an estimated canine population of 270,677 , which is a ratio of one dog to 8.24 inhabitants $^{2}$, and little is known about the prevalence and control of canine parasites. Therefore, we designed this study to investigate soil contamination in public squares, which are leisure and recreation areas for children, with developmental stages of the canine parasites with zoonotic potential.

\section{METHODS}

The study was conducted between the months of March and September 2011. The regions north and south of Belo Horizonte have 46 and 137 squares, respectively, according to information provided by the municipality. Of these squares, the 21 most frequented by local people were selected in each of the northern and southern regions of the city. Five "pools" of soil were collected from each of the 42 recreation areas, which weighed a total of $200 \mathrm{~g}$ and represented a soil sample. The feces of dogs were collected, with the aid of a spatula, and stored in plastic bags, which had been previously identified. Both samples, i.e., soil and feces, were placed in an isothermal box with ice packs and transported the same day to the Veterinary Helminthology Laboratory at the Institute of Biological Sciences, Federal University of Minas Gerais, for

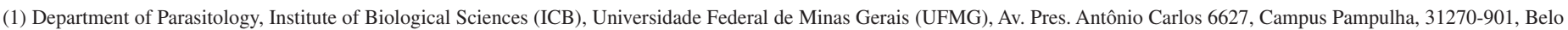
Horizonte, MG, Brazil. E-mails: lucianemadureiraster@gmail.com, rutinhamd@yahoo.com.br, lanuze@yahoo.com.br

(2) Postdoctorate in parasitic diseases from Louisiana State University, USA. E-mail: wlima@icb.ufmg.br

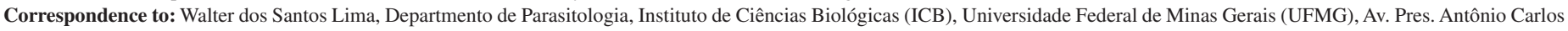
6627, Campus Pampulha, 31270-901 Belo Horizonte, MG, Brasil. E-mail: wlima@icb.ufmg.br 
RIBEIRO, L.M.; DRACZ, R.M.; MOZZER, L.R. \& LIMA, W.S. - Soil contamination in public squares in Belo Horizonte, Minas Gerais, by canine parasites in different developmental stages. Rev. Inst. Med. Trop. Sao Paulo, 55(4): 229-31, 2013.

examination. Soil samples were analyzed by the Caldwell and Caldwell technique modified by CORRÊA ${ }^{5}$ to detect eggs, cysts, or oocysts. For fecal analysis, the Hoffman, Pons, and Janner ${ }^{10}$ technique was used. The examination was performed under a light microscope with $10 \times$ and $40 \times$ objective lenses. The chi-square test was used to assess the association between the occurrence of parasites and the geographic location of the square from which the fecal and soil samples were collected. A $p$ value of $<0.05$ was considered statistically significant.

\section{RESULTS}

A total of 210 soil samples (105 each from the northern and southern areas) and 141 fecal samples (71, northern; 70, southern) were collected from March to September 2011. Of these, 89 (42.4\%) soil samples (46, northern; 43, southern) and 104 (73.5\%) fecal samples (55, northern; 49, southern) were contaminated. In the soil and fecal samples, Ancylostoma sp., Toxocara sp., Trichuris sp., and Dipylidium sp. eggs; Giardia sp. cysts; and Isospora sp. oocysts were found, as shown in Table 1.

Table 1

Parasites found in contaminated soil and fecal samples of public squares in the municipality of Belo Horizonte, MG

\begin{tabular}{lcc}
\hline Parasites & Soil & Feces \\
\hline Ancylostoma sp. & $85.0 \%(76 / 89)$ & $99.0 \%(103 / 104)$ \\
Toxocara sp. & $43.7 \%(39 / 89)$ & $30.7 \%(32 / 104)$ \\
Giardia sp. & $9.2 \%(8 / 89)$ & $15.4 \%(16 / 104)$ \\
Trichuris sp. & $8.0 \%(7 / 89)$ & $6.7 \%(7 / 104)$ \\
Isospora sp. & $2.3 \%(2 / 89)$ & $1.9 \%(2 / 104)$ \\
Dipylidium sp. & $1.1 \%(1 / 89)$ & $0.9 \%(1 / 104)$ \\
Entamoeba sp. & $0.0 \%(0 / 89)$ & $0.9 \%(1 / 104)$ \\
\hline
\end{tabular}

Thirty-seven of the soil and 45 of the fecal samples showed associations between parasites, and a combination of Ancylostoma sp. and Toxocara sp. was most frequent (Table 2).

Table 2

Associations between parasites in soil and fecal samples of the squares of Belo Horizonte

\begin{tabular}{lcc}
\hline Association type & Soil & Feces \\
\hline Ancylostoma/Toxocara & $56.85 \%(21 / 37)$ & $44.4 \%(20 / 45)$ \\
Ancylostoma/Isospora & $2.63 \%(1 / 37)$ & $4.6 \%(2 / 45)$ \\
Ancylostoma/Giardia & $10.65 \%(4 / 37)$ & $19.4 \%(9 / 45)$ \\
Ancylostoma/Trichuris & $10.8 \%(4 / 37)$ & $12.9 \%(5 / 45)$ \\
Toxocara/Trichuris & $2.75 \%(1 / 37)$ & $0.0 \%(0 / 45)$ \\
Ancylostoma/Giardia/Trichuris & $0.0 \%(0 / 37)$ & $1.85 \%(1 / 45)$ \\
Ancylostoma/Toxocara/Giardia & $8 \%(3 / 37)$ & $10.15 \%(5 / 45)$ \\
Ancylostoma/Toxocara/Dipylidium & $2.63 \%(1 / 37)$ & $1.85 \%(1 / 45)$ \\
Ancylostoma/Toxocara/Entamoeba & $0.0 \%(0 / 37)$ & $1.85 \%(1 / 45)$ \\
Ancylostoma/Toxocara/Trichuris & $5.55 \%(2 / 37)$ & $2.75 \%(1 / 45)$ \\
\hline
\end{tabular}

The chi-square test showed no significant difference $(p=0.4241)$ between the proportion of infected samples in the two areas studied (Table 3).

Table 3

Association between the presence of parasites in soil and fecal samples collected in public squares, grouped in two areas in the city of Belo Horizonte, MG

\begin{tabular}{lcccc}
\hline \multirow{2}{*}{ Area } & \multicolumn{2}{c}{ Soil / Fecal Samples } & & \multirow{2}{*}{$X^{2}$} \\
\cline { 2 - 3 } & Positive & Negative & & $p$ Value \\
\hline North & 101 & 75 & 0.639 & 0.4241 \\
South & 92 & 83 & & \\
\hline
\end{tabular}

\section{DISCUSSION}

Several studies ${ }^{4,5,16}$ have been conducted on soil contamination with eggs, cysts, oocysts, and larvae of zoonotic parasites in public places of leisure, such as squares and parks. In this study, conducted in the squares of Belo Horizonte, we observed the presence of a large number of owned and stray dogs, which may explain the significant amount of feces in the environment. This observation is consistent with the findings of SERRANO et al. $(2000)^{22}$, who evaluated the soil contamination by Toxocara sp. eggs in public parks in Peru and concluded that the most polluted parks were those with the most stray dogs.

A high percentage of Ancylostoma sp. eggs was observed in the soil samples, which is consistent with the results of ALMEIDA et al. (2007) ${ }^{1}$, who found Ancylostoma sp. in $83.3 \%$ of the samples from public squares in Cuiaba in Mato Grosso, Brazil.

The most common parasite in all samples analyzed was Ancylostoma sp., which is consistent with the findings of SCAINI et al. $(2003)^{20}$, who confirmed environmental contamination of Balneário Cassino in Rio Grande do Sul, Brazil, and the findings of CAPUANO \& ROCHA (2006) ${ }^{4}$ in the municipality of Ribeirao Preto in Sao Paulo State, Brazil. In the fecal analysis, some associations between parasites were found; the most between Ancylostoma sp. and Toxocara sp., followed by Ancylostoma sp. and Giardia sp.; Ancylostoma sp. and Trichuris sp.; Ancylostoma sp. and Isospora sp.; and Ancylostoma sp., Giardia sp., and Trichuris sp. These associations are similar to those reported by CAPUANO \& ROCHA $(2006)^{4}$, who discovered six associations between parasites, and ALMEIDA et al. (2007) ${ }^{10}$, who observed two associations, Ancylostoma sp. and Toxocara sp., and Ancylostoma sp. and Trichuris vulpis. These results differ from those obtained by SCAINI et al. $(2003)^{20}$, who reported frequent associations of Ancylostoma sp. and Trichuris sp., followed by Ancylostoma sp., Trichuris sp., and Toxocara sp.; and Ancylostoma sp. and Toxocara sp.

The frequency of Isospora sp. oocysts was $2.3 \%$ and $1.9 \%$ in soil and fecal samples, respectively, which was lower than that found by CAPUANO \& ROCHA (2006) ${ }^{4}$. Similarly, no statistically significant differences were found in previous studies ${ }^{24}$ that grouped the squares of the city by regions. The most frequent parasites in soil and fecal samples of the squares of Belo Horizonte were Ancylostoma sp. and Toxocara sp., and the quantity, diversity, and associations between parasites were 
greater in fecal than in soil samples. The results show the frequency of different parasites at all sites of collection (Table 1). Because the environment is an important focus of contamination and it allows for the persistence of viable eggs, there is a possibility of human infection, mainly infection of children playing on soil of public squares.

It is important that people be informed of the need to treat domestic animals and control animal breeding in order to minimize the number of stray animals, as domestic and stray animals are disseminators of zoonotic parasites. The importance of periodic control of gastrointestinal parasites in dogs, based on correct diagnosis and appropriate use of antiparasitics, should be emphasized.

\section{RESUMO}

\section{Contaminação do solo em praças de Belo Horizonte, MG, por estádios evolutivos de parasitos de cães}

Visando avaliar a contaminação do solo por estágios evolutivos de parasitos em praças públicas utilizadas como áreas de lazer e recreação infantil em Belo Horizonte (MG, Brasil) foram coletadas 210 amostras de solo e 141 amostras de fezes de cães em 42 praças do município. Estas amostras foram analisadas pelas técnicas de Caldwell \& Caldwell, Hoffmann, Pons, Janer. Do total das amostras analisadas, $89(42,4 \%)$ amostras de solo e $104(73,5 \%)$ amostras de fezes estavam contaminadas com ovos de Ancylostoma sp., Toxocara sp., Trichuris sp. e Dipylidium sp.; cistos de Giardia sp; oocistos de Isospora sp., sendo o parasito mais freqüente Ancylostoma sp. com $85 \%$ no solo e $99 \%$ nas fezes, seguido por $43,7 \%$ no solo e $30,7 \%$ nas fezes de Toxocara sp.

\section{REFERENCES}

1. Almeida ABPF, Sousa VRF, Dalcin L, Justino CHS. Contaminação por fezes caninas das praças públicas de Cuiabá, Mato Grosso. Braz J Vet Res Anim Sci. 2007;44:132-6.

2. Borges BKA, Silva JA, Haddad JPA, Moreira EC, Magalhães DF, Ribeiro LML, et al. Avaliação do nível de conhecimento e de atitudes preventivas da população sobre a leishmaniose visceral em Belo Horizonte, Minas Gerais, Brasil. Cad Saúde Pública. 2008;24:777-84

3. Buijs J, Borsboom G, Renting M, Hilgersom WJ, Van Wieringen JC, Jansen G, et al Relationship between allergic manifestations and Toxocara seropositivity: a crosssectional study among elementary school children. Eur Respir J. 1997;10:1467-75.

4. Capuano DM, Rocha GM. Ocorrência de parasitas com potencial zoonótico em fezes de cães coletadas em áreas públicas do município de Ribeirão Preto, SP, Brasil. Rev Bras Epidemiol. 2006;9:81-6.

5. Corrêa GLB, Moreira WS. Soil contamination due to eggs of Ancylostoma spp. in public parks of the city of Santa Maria, RS, Brazil. Rev Fac Zootec Vet Agron. 1995/1996;23(1):15-7.

6. Endenburg N, Baarda DB. The roles of pets in enhancing human well-being: effects on child development. In: Robinson I, ed. The Waltham Book of Human-Animal Interaction: Benefits and Responsibilities of Pet Ownership. Oxford: Pergamon; 1995. p. 1-17.

7. Gauthier JL, Richardson DJ. Knowledge and attitudes about zoonotic helminths: a survey of Connecticut pediatricians and veterinarians. Compend Contin Educ Pract Vet. 2002;24:4-9.
8. Grant S, Olsen CW. Preventing zoonotic diseases in immunocompromised persons: the role of physicians and veterinarians. Emerg Infect Dis. 1999;5:159-63.

9. Hart AL. Positive effects of animals for psychosocially vulnerable people: a turning point for delivery. In: Handbook on animal-assisted therapy: theoretical foundations and guidelines for practice. $3^{\text {rd }}$ ed. San Diego: Academic Press; 2010. p. 59-84.

10. Hoffmann WA, Pons JA, Janner JL. The sedimentation concentration method in schistosomiasis mansoni. Puerto Rico J Public Health Trop Med. 1934;9:283-91.

11. Khoshoo V, Schantz P, Craver R, Stern GM, Loukas A, Prociv P. Dog hookworm: a cause of eosinophilic enterocolitis in humans. J Pediatr Gastroenterol Nutr. 1994;19:448-52.

12. Lima WS, Camargo MCV, Guimaraes MP, Leite ACR. Surto de larva migrans cutânea em uma creche de Belo Horizonte, MG. Rev Inst Med Trop Sao Paulo. 1984;26:122-4.

13. Lima WS. Larva migrans. In: Neves DV, ed. Parasitologia humana. 11. ed. São Paulo: Atheneu; 2005. p. 271-4

14. Malgor R, Oku Y, Gallardo R, Yarzabal I. High prevalence of Ancylostoma spp. infection in dogs, associated with endemic focus of human cutaneous larva migrans, in Tacuarembo, Uruguay. Parasite. 1996;3:131-4.

15. Marmor M, Glickman L, Shofer F, Faich LA, Rosenberg C, Cornblatt B, et al. Toxocara canis infection of children: epidemiologic and neuropsychologic findings. Am J Public Health. 1987;77:554-9.

16. Mercado R, Ueta MT, Castillo D, Muñoz V, Schenone H. Exposure to larva migrans syndromes in squares and public parks of cities in Chile. Rev Saúde Pública. 2004;38:729-31

17. Minnaar WN, Krecek RC, Fourie LJ. Helminths in dogs from a peri-urban resource-limited community in Free State Province, South Africa. Vet Parasitol. 2002;107:343-9.

18. Nolan TJ, Smith G. Time series analysis of the prevalence of endoparasitic infections in cats and dogs presented to a veterinary teaching hospital. Vet Parasitol. 1995;59:8796

19. Raina P, Waltner-Toews D, Bonnet B, Woodward C, Abernathy T. Influence of companion animals on the physical and psychological health of older people: an analysis of a one-year longitudinal study. J Am Geriatr Soc. 1999;47:323-9.

20. Scaini CJ, Toledo RN, Lovatel R, Dionello MA, dos Anjos Gatti FA, Susin L, et al. Contaminação ambiental por ovos e larvas de helmintos em fezes de cães na área central do Balneário Cassino, Rio Grande do Sul. Rev Soc Bras Med Trop. 2003:36:617-9.

21. Schantz PM, Weis PE, Pollard ZF, White MC. Risk factors for toxocaral ocular larva migrans: a case control study. Am J Public Health. 1980;70:1269-72.

22. Serrano M, Chavez V, Casas A. Contaminación de parques públicos Del Cono Este con huevos de Toxocara sp. Rev Investig Vet Perú. 2000;11:82-7.

23. Stehr-Green JK, Schantz PM. The impact of zoonotic diseases transmitted by pets on human health and the economy. Vet Clin North Am Small Anim Pract. 1987;17:1-15.

24. Stull JW, Carr AP, Chomel BB, Berghaus RD, Hird DW. Small animal deworming protocols, client education, and veterinarian perception of zoonotic parasites in western Canada. Can Vet J. 2007:48:269-76.

Received: 16 October 2012

Accepted: 2 January 2013 